\title{
ZPRÁVY
}

\section{Informace o výzkumném záměru katedry sociologie}

\author{
Název výzkumného záměru: \\ Vysoká škola: \\ Fakulta \\ Rešitel: \\ Identifikačni kód: \\ Plánovaná doba řešeni: \\ Ročni rozpočet:
}

\author{
Jedinec a společnost $v$ procesech transformace a globalizace \\ Univerzita Karlova \\ filozofická \\ doc. PhDr. Jiř́ Buriánek, CSc. \\ CEZ: J13/98:112100001 \\ 1999-2003 \\ cca 2,5 mil. Ǩ
}

\section{Cîe výzkumného záměru a strategie jejich dosažení}

Záměr byl formulován velmi operativně v řijnu 1998 vlastně až v prủběhu jednání vědecké rady FF UK o tehdy nově koncipovaném typu vědeckých projektů, které měly dlouhodobě profilovat instituce. Podařilo se prosadit nejen samo téma, ale také představu, že samostatnou profilaci (a z ní vyplývající rozvojové potenciály) zasluhuje mezi ostatními i skupina oborủ, které je možno uvnitř značně heterogenní fakulty považovat za reprezentanty social sciences, tedy společenských věd $\mathrm{v}$ užším slova smyslu. Je třeba přiznat, že tento strategický motiv převážil nad teoretickým a že projekt od počátku směřoval $\mathrm{k}$ heuristicko-exploračnímu a nikoli verifikačnimu pojetí. Bylo by arcit vrcholně nespravedlivé osočovat řešitelský tým z čirého pragmatismu, ostatně pouze na tomto základě by projekt nemohl $\mathrm{v}$ tvrdé soutěži s jinými obstát.

Formulace výzkumného problému staví od počátku především na vědách psychologických a na sociologii, využivá dále zapojeni pedagogiky, kulturologie a ekonomie. Tato nesporně žádoucí integrace usiluje o spojení dvou tematických linií, které vyjadřuje název projektu:

- Specifikou rady participujících oborủ je jejich zájem o problematiku lidského jednání a utvá- ření osobnosti, $v$ poněkud širším pojetí pak aktivního sociálního aktéra. Protože tyto otázky nelze studovat mimo konkrétní sociální kontext, stavíme do centra zájmu dynamicky chápaný vztah jedince a společnosti, aktéra a sociálního systému. Dílčím cílem výzkumného záměru bude mimo jiné též studium mechanismů zprostředkování tohoto vztahu, tj. např́klad institucionálních aspektů (studium fungování systému vzdělávání, organizací, trhu).

- Výzkum takto exponované otázky nelze izolovat od časoprostorových koordinát. Namísto módních studií soustředujících se na zlom tisíciletí zdůrazñujeme vzájemný vztah dvou klíčových procesů. Na jedné straně je třeba analyzovat postup transformace české společnosti v nejrủznějších oblastech (formováni sociální struktury, hodnotového a normativního systému, utváření občanské společnosti, problémy přizpủsobení jednotlivce novým společenským podmínkám), na druhé straně nelze ztratit ze zřetele globální procesy probíhající v rámci celého světa (hledání nových forem kulturní identifikace a integrace, a to nejen $v$ horizontu evropských struktur). Vznikají zde otázky po 
dalším směrování, možnostech i důsledcích modernizačních procesů na makro- i mikroúrovni.

Z metodologického pohledu úkol vyžaduje propojení teoretických a empirických přístupů. $\mathrm{K}$ analýze teoretických aspektủ se dlouhodobě orientují katedry sociologie a psychologie. Obohacení na úseku výzkumu institucionálních a pragmaticky formativních aspektủ lze očekávat od kateder pedagogiky, kulturologie a ekonomie. Výzkumný záměr významně posílil možnosti realizace samostatných empirických výzkumủ (v roce 2000 kulturologie, $v$ roce 2001 sociologie).

Ačkoliv jde o téma velmi komplexní a relevantní především teoreticky, počítá se i s jeho aplikačními přsesahy. Zdaleka nejde jen o tradični propojení na výuku, do výchovných a učebních programů. Řada navržených témat sleduje vazbu na sféru výroby (např. komparace odvětví, podnikủ), organizací všeho druhu, otázky rozvoje komunit a místních společenství (včetně otázek životního stylu, problematiky prevence patologických jevů apod.). I když výzkumný projekt volně navazuje na celou řadu jednotlivých účelových grantů, je pojat jako nový a zcela samostatný úkol, který směruje $\mathrm{k}$ interdisciplinárnímu pojetí problému. Byl koncipován na celých pět let (1999-2004). Poslední rok řešení bude věnován pracím na syntéze ( $v$ podobě souhrnné monografické publikace).

\section{Kličové výsledky prvních tří let řešení projektu}

Během prvního roku řešení ještě probíhala schvalovací procedura a upřesňování projektu včetně evidenční administrativy. Byly dohodnuty formy koordinace, které se řídí demokratickými principy a vycházejí z konsenzuálního přistupu. Takto jsme přistoupili například i $\mathrm{k}$ rozdělení finančních prostředkủ. S ohledem na počet témat a řešitelủ se jevilo jako zdůvodněné dát zhruba polovinu rozpočtu $\mathrm{k}$ dispozici dvěma psychologickým pracovištím (katedře a ústavu). I když se větší část prostředkủ dělí zhruba podle podílu jednotlivých pracovišt', byla současně schválena zásada, že část prostředkủ bude $\mathrm{v}$ každém roce přidělena některému týmu $\mathrm{k}$ realizaci náročnějších terénních šetření.

Projekt je také chápán jako otevřený. V období let 2000-2001 se k němu přpojila i katedra filozofie. Základní řešitelský kolektiv tvořili na počátku vedoucí všech zainteresovaných pracovišt, kteři vystupovali jako garanti jednotlivých př́spěvkủ a koordinátoři dílčích úkolủ. Postupem času došlo jak k dílčím obměnám, tak i k rozšîréení dělby práce. Celková kapacita pro řešení úkolu je totiž značně rozsáhlá: ke spolupráci se přihlásilo 82 řešitelủ ( $\mathrm{z}$ větší části interní pracovníci FF UK, dílem doktorandi). To i při průměrném pracovním fondu 0,25 predstavuje více než 20 plných ročních úvazkủ, tj. minimálně 38000 hodin ročně. Charakter úkolu přitom umožní formovat pružné týmy $\mathrm{k}$ jednotlivým tématům, takže do budoucna by výchozi ,oborová“ struktura měla být nahrazena strukturou „tematickou“ (náměty jako „formování osobnosti“, „„̌ivotní styl a kultura“, ,zaměstnanost, práce a podnikání“, ,rizika“). V týmu panuje obecná shoda v tom, že účast na řešení by neměla být formálni a že není vhodné připustit nadměrnou diverzitu témat a př́stupů. Významným kritériem zůstává kvalita výstupů a kázeň $v$ dodržování stanovených pravidel.

Projekt nebyl podroben vstupní oponentuře, postup řešení byl kontrolován formou průběžných oponentních řizení (evaluace vědeckou radou $\mathrm{FF}$ a UK). $O$ to důležitější se stala celková evaluace projektu naplánovaná MS̆MT na rok 2001. Hodnocen byl nejen původní projekt, ale také hlavní výstupy za první fázi řešení. Výzkumný záměr prošel úspěšně evaluací $s$ celkovým hodnocením komise $B$ a se závěrem pokračovat ve financování projektu. Vẽtšina oponentských posudků hodnotila projekt nejvyšším stupněm.

$\mathrm{V}$ prủběhu let 2000-2001 byly publikovány některé významné studie. Uskutečnila se také náročnějši výzkumná šetření a samostatné prezentace výsledků:

1. V roce 2000 provedla katedra kulturologie dalši fázi longitudinálního výzkumu tři českých měst.

2. Katedra sociologie realizovala rozsáhlý empirický výzkum „,Aktér 2001“ na vzorku dvou tisíc respondentủ, který vytvoří rozhodujicí empirickou bázi pro syntetickou fázi projektu.

3. Katedra psychologie organizovala v Praze mezinárodní kongres psychologie práce $\mathrm{v}$ květnu 2001, v řijnu pak česko-polskou konferenci.

Během posledního roku se ukázalo, že zapojení katedry filozofie nepřineslo organičtější tematické propojení a efektivní spolupráci, proto katedra sama požádala o dočasné utlumení svého zapojení do projektu. To může být obnoveno, pokud se taková potřeba v budoucnosti objeví. Naopak ostatní zapojená pracoviště postupují podle plánu řešení a vykazuji relevantní výsledky. Osvědčilo se rozdělení prostředkủ na jednotlivá střediska, zlepšila se mimo jiné také kázeň jednotlivých řešitelů při jejich čerpání.

Objevují se některé nové možnosti zahraniční spolupráce - napřr. u katedry sociologie s prof. Ishikawou z Chuo University Tokyo, u psychologů významně prispěly mezinárodní konference. 


\section{Anotace záměrů dilčích týmů}

\section{Psychologie}

Řešitelé se významným způsobem podíleli na přípravě a realizaci česko-polské konference na téma Psychologické aspekty procesu transformace $\mathrm{v}$ hospodár̆ské oblasti, která se konala v Praze 9. řjina. 2001 prènesené přispěvky jsou publikovány ve sborníku $\mathrm{z}$ konference. Průběžné výsledky řešení úkolủ byly prezentovány na 10 . evropském kongresu psychologie práce a organizace, který proběhl v květnu 2001 (zaměření kongresu: Globalizace - př́nosy a problémy). I v tomto případě budou přednesené přispěvky řešitelủ otištěny v konferenčním sborníku. Pro období roku 2002 představuje těžiště zpracování a rozbor získaných dat (např. výzkum zájmủ z roku 2001 provedený u dvou tisícủ dětí a mladistvých). Na přelom roku byla připravena publikace Psychologické problémy člověka v měnícím se světě II.

\section{Pedagogika}

Tematické zaměření úkolu katedry pedagogiky je „Člověk a výchova v kontextu současných globalizačních tendencí". Realizovaný projekt je řešen v úzké spolupráci týmu vysokoškolských učitelů, doktorandů, studentů i učitelů $\mathrm{z}$ praxe. Postupné rozpracování tematiky probíhá $\mathrm{v}$ návaznosti na předchozí činnosti r̆ešitelského týmu. Ve všech dále uvedených oblastech je rozvinuta zahraniční spolupráce - jako spoluřešitelé byli do úkolu zapojeni kromě jiných odborníků: prof. ing. Adolf Melezinek (Rakousko), prof. dr. Ewa Marynowicz-Hetke (Polsko), prof. dr. Boguslaw Sliwerski (Polsko) a prof. dr. Petr Ondráček (Německo).

- Fenomén globalizace v zorném úhlu pedagogiky a její historické aspekty

- Model kooperativního učení a rozvoj individuality v sociálním kontextu

- Hodnoty ve výchově a globalizovaný svět sociálněpatologické jevy ve společnosti

- Kurikulum české školy - projektová a realizační podoba $\mathrm{z}$ hlediska orientace na osobnost a sociální dovednosti

- Sociální kompetence jako významný předpoklad autority učitele - možnosti jejího rozvíjení

- Proces učení a poznávání v kontextu osobnostního rozvoje (se zaměřením na možnosti metakognitivního nácviku)

- Změny v pojetí výchovy v postmoderní společnosti

- Plánované odborné záměry pro následujicí etapu zpracování úkolu: v r. 2002-2003 pủjde o závěrečné zprávy $\mathrm{z}$ výzkumu a teoretických analýz zpracované do sborníku či monotematického čísla časopisu Pedagogika (,Vybrané otázky výchovy a vzdělávání v kontextu globalizačních tendenci“")

\section{Ekonomie}

Dílčí úkol Ekonomická emancipace jedince $v$ procesu transformace a globalizace pokračoval ve trech rovinách zkoumání: jedinec (domácnost) jako spotřebitel, pracovník (producent) a hospodár (podnikatel, investor). Výsledkem jsou studie:

- Sociálně ekonomická pozice domácností ve smíšené ekonomice (J. Vlček)

- Aktuální stav v oblasti vzdělávání na přelomu tisíciletí (J. Strádalová)

- Moderní bankovní technologie a drobní investoři (V. Košteková)

- Právní aspekty transformace české ekonomiky a ekonomická emancipace (J. Večeř)

- Ceská ekonomika a její zapojení do globalizačních a integračních procesů (A. Smutná)

- Evropské hospodářské zájmové sdružení, nová forma nadnárodní hospodářské kooperace na trhu EU (M. Bednaříková)

Přípravou na terénní výzkum v roce 2002 byl předběžný výzkum, který byl realizován v České gumárenské společnosti, a.s., v Rubeně Hradec Králové a Buzuluku Komárov. Jeho cílem bylo získat základní informace o marketingové strategii jednotlivých obchodněpodnikatelských jednotek a o podnikové kultuře.

\section{Kulturologie}

U projektu Globálni a lokálni kultura. Transformace mëstských komunit v kontextu evropských integračnich procesů byla provedena analýza dat pocházejících jednak $z$ šetřeni reprezentativních vzorkủ dospělé populace měst Blatná, Ceský Krumlov a Velké Meziřičí v roce 2000, jednak z komparace obdobných šetření uskutečněných ve dvouletých obdobích od roku 1992. Hlavním výstupem bylo vypracování tř̌i monografických studií. Součástí řešení výzkumného záměru byla i připrava rozsáhlejších empirických šetření v roce 2002.

\section{Sociologie}

Rok 2001 byl věnován přípravě projektu empirického výzkumu, upřesnění hypotéz a tvorbě dotazníkủ, výzkum byl obohacen o některé okruhy díky zapojení doktorandủ. Katedra se významně podílela na přípravě monotematického čísla Sociologického časopisu $\mathrm{k}$ bezpečnostním rizikům, na organizaci semináře ke globalizaci na UK (prosinec 2001). 
$V$ roce 2002 začne publikace výsledkủ empirického šetření zejména $v$ rámci sborníku AUC. Plánuje se účast na konferenci v Japonsku a zřejmě také prezentace výsledků na světovém kongresu ISA.

\section{Výzkum aktéra a výsledků transformace $v \check{C} R$ v roce 2001}

Jedním $\mathrm{z}$ cílů této zprávy je rekapitulace východisek provedeného sociologického výzkumu výsledkủ transformace $\mathrm{v}$ rovině hledání nové identity a základních životních strategii aktérủ. Není určena jenom členủm týmu nebo řešitelủm $z$ dalších pracovišt. Získaný datový soubor otevírá možnosti participace studentủ, doktorandủ i dalších badatelů nejen z FF UK, ale i z dalších institucí. Výzkumný tým hledal poměrně dlouho cestu ke koncepci výzkumu, nebot téma nabízelo několik možností řešení. Dlouhou dobu vystupoval do popředí koncept identity (který měl umožnit uchopení problémů globalizace i transformace), v soutěži však nakonec obstály lépe jiné alternativy.

Na počátku byly formulovány určité základní strategické představy o cílech empirického šetření v roce 2001. Základní východiska projektu předpokládala:

- pojednat sociologické aspekty nově, a zároveň komplementárně (ve vazbě na výsledky týmu Machonina a Tučka),

- zachovat interdisciplinaritu (posílit možnosti spolupráce s ekonomy, s psychologií nebo třeba i lingvistikou),

- práci $\mathrm{s}$ velkým reprezentativním souborem (2000 respondentů, původně nad 15 let), maximální rozsah 16 stránek dotazníku,

- taxativní operacionalizaci na principu skládanky (s naznačením základní strategické osy uvnitř každé oblasti), to by umožnilo zařazení několika relativně samostatných okruhủ (podle zájmu a orientace jednotlivých řešitelü).

Možné schéma uvnitř každé z oblastí:

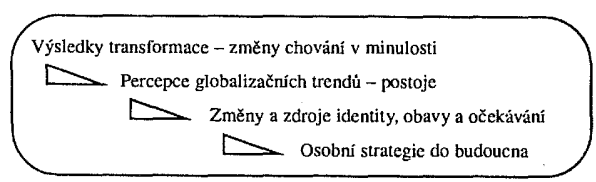

\section{Výchozi taxonomie tematických okruhü:}

1. Práce, zaměstnání, podnikatelské a obživné strategie (též jako podklad pro následujici podnikové studie připravované katedrou ekonomie)

2. Technologické změny a modernizace $v$ práci a v rodině, způsoby komunikace (jazyk)
3. Hodnoty spojené s prací a vzděláním, strategie a flexibilita ve sféře práce

4. Kultivace lidského potenciálu - volný čas

5. Prostorové dimenze globalizace - fenomén cestování

6. Identita - osobní, regionální, národní, evropská problémy integrace do Evropy

7. Percepce změn jako problém sociálního času horizonty a konstrukce budoucnosti

8. Participační a občanské strategie (instituce, organizace, autority)

9. Konzumní strategie a problém omezeného růstu 10. Rizika vývoje a potenciály dủvěry (Collinsủv pojem credentiality)

11. Sociodemografické proměnné

Základní shoda byla v tom, že výzkum by měl sledovat též linii regionálního pohledu a stratifikačních efektủ. Ve výchozí taxonomii bylo ovšem nutno stanovit priority. Rozhodování pozitivně ovlivnilo zapojeni nových doktorandủ, kteři přinesli některé zajímavé náměty. $\mathrm{K}$ pủvodním námětům pak byla formulována řada heuristických otázek. Pro ilustraci uvedeme některé $\mathrm{z}$ nich:

Odezněla již fáze podnikatelskêho boomu? Jsou již patrné efekty vytvořeného trhu práce? Zvyšuje se flexibilita pracovni sily? Jaky je podíl druhého zaměstnání, popřipadě šedé ekonomiky? Funguje tendence ke konzumu, anebo protestantská etika? Změnil se obsah práce? Jak významný modernizační potenciál nesou počitače? Jaká média se používaji (jazyková stránka komunikace včetně cizich jazykui)? Jak moc lidé cestuji - nejen rekreačnĕ, ale služebně, za vzdělánim? Co lidé oceňuji na zaměstnáni, je to primárni zdroj identity? Jak (moc) lidé plánuji budoucnost? Nakolik jsou sebevědomými aktéry změny? Kdo mủže ovlivnit jejich rozhodováni? Vnimaji dostatečně některá rizika (ekologická, zdravotni)? Kde se bere divěra v budoucnost, v instituce, ve druhé lidi, $v$ „jiné "lidi (xenofobie)?

Má smysl konstruovat nĕjaké syntetické promĕnné „promodernizačni orientace " nebo škály antiglobalismu?

Jakou relevanci má v současné době generační rozdil, kde leži hranice nebo preděly?

Jak spojit jedince a společnost - brát ohled na zprostředkujici úlohu rodiny, generace, sociálni sitě??

$\mathrm{K}$ výsledkủm diskuse patřilo to, že nebude sledována nějaká jednotná pro- nebo protiglobalizační (modernizační atd.) tendence. Zájem o problematiku jedince nakonec oslabil váhu konceptu identity, 
a to zejména $v$ jeho národních a historických komponentách. Jako nejnosnější se ukázaly momenty rozhodování a motivace aktéra. $Z$ toho pak vyplynula shoda, pokud jde o význam taxonu hodnotových orientací a okruhu otázek na potenciály důvěry. Bylo přijato pracovní označení výzkumu jako „Aktér 2001“ a navržen dotazník na základě modifikovaného operacionálního modelu (obr. 1).

Problém identity aktéra se posunul směrem $\mathrm{k}$ mnohovrstevnatému konceptu důvěry. Zkoumání hodnotových orientací bylo rovněž založeno na představě vrstev (hodnoty společenskopolitické, individuální, hodnoty jako strategické životní volby, hodnoty jako perspektivní strategie - projekce do výchovy dětí). Chceme upozornit, že i v tomto přístupu byly některé složky vědomě potlačeny. Například bylo možno rozlišit následující vrstvy duvěry:

- sebedůvěra

- známí

- komunita (zařazeno jen v omezeném rozsahu)

- organizace, úrady

- instituce (jen vybrané)

- systém (potlačena na minimum)

- hodnoty, strategie, cíle

Hledání konzistentního výkladového rámce $\mathrm{v}$ určité fázi vedlo $\mathrm{k}$ převedení východiskových hypotéz do poměrně abstraktního a univerzálního schématu, který odpovídá tradičnímu pohádkovému mýtu (jakési archetypální struktuře, která spoluprovází aktéra na jeho cestě dějinami). Ve výzkumu samožrejmě nepůjde o to tento model nějak ,,verifikovat“. Očekâváme spíše výskyt určitých modifikací onoho zdánlivě věčného príběhu. Jedna $z$ jeho pracovních verzí může vypadat třeba takto:

Hrdina sociälně determinovaný rodinou (dosadit lze i poměrně konkrétně: Honza, princ, atd.) hledá svou identitu na cestě za strategickým cílem, cestou získává balíček věděni (obvykle též jako schopnost komunikovat a důvěra investovat!), hledá partnerku, zabiji draka (hle: rizika!), plní rozličné úkoly (práce). To vše má hodnotový a institucionálni rámec (rozhoduje férový souboj, anebo legitimní lest, či podfuk?).

Je tedy jistě odvážnou intencí našeho výzkumu pokusit se tento př́iběh převyprávět (arcit na podkladě zcela tradičně, tedy kvantitativně založené datové báze). Nejde nám o narativní sociologii, ale o takové pojetí aktéra, které se nerozplyne v nadměrně abstrakci, ve složitých systémových vazbách.

V dotazníku, který byl snímán technikou standardizovaného rozhovoru v listopadu 2001, lze najít následující bloky otázek:

1. Hodnoty a životní strategie

2. Zaměstnání a práce včetně spokojenosti s prací, perspektivami v zaměstnání

3. Zájmy a volný čas, čtenářské zájmy, sledovâní televize

4. Autority, sociální okruh, komunita a sociální podpora okolí

5. Dủvěra $\mathrm{k}$ institucím, $\mathrm{k}$ lidem

6. Vývoj společnosti, rizika a obavy

7. Sebehodnocení aktéra (polaritní profil, sebepojetí v poloprojektivní technice dělení kruhu)

8. Národní identifikace, politické preference

9. Znalosti, dovednosti, změny zaměstnání

10. Rodina

11. Životní úroveň, investiční strategie

12. Cestování

Dotazník je ovšem třeba vnímat jako celek, jednotlivé bloky na sebe poměrně těsně navazují. Provedené redukce podle našeho soudu prispěly $\mathrm{k}$ tomu, že se šetření nerozpadlo do oddělených fragmentů. Naopak dotazník umožňuje i některé prúřezové analýzy, např. téma rodiny se objevuje v několika blocích a vytváří poměrně zajímavý celek.

Podrobnější údaje o datovém souboru najde čtenář ve stati J. Buriánka v tomto sborníku. Jinak je možno obracet se na katedru, vážným zájemcủm poskytneme podrobnější informace o struktuře dotazníku a o možnostech využití dat.

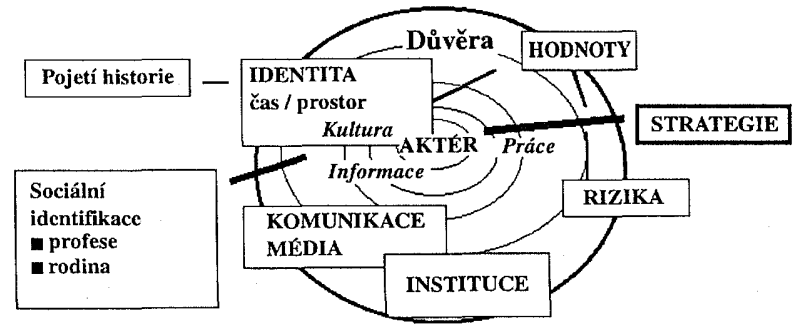

Obr. I-AKTÉR 001: Model operacionalizace 
Významné publikace za dobu řešení projektu (výběr ze všech pracovišt'):

KOL. (ed. J. ŠUBRT) 2000. Společenské procesy a jejich aktéri, AUC Phil. et Hist. 4/I997, Studia sociologica XII, Praha: Karolinum.

- Suša, O.: Sociologie globalizace: problémy a př́stupy.

- Šubrt, J.: Východiska Giddensova př́stupu k rekonstrukci sociální teorie.

- Duffková, J.: Mnohovýznamovost ne/gramotnosti.

- Rủžička, R.: Aktéři, struktury a šance v transformaci společnosti.

SUŠA, O. 2000. „Beckovo pojetí světové rizikové společnosti jako příspěvek k diskusi o globalizaci“. In: Jedinec a společnost. Praha: FF UK, s. 145-156.

DUFFKOVÁ, J. 2000. „Současná struktura mimopracovního času a její změny za posledních deset let“. In: Výzkum společenské struktury a mobility 1999. Data \& Fakta, č. 2-10.

MUCHA, I. 2000. Symboly v jednání. Praha: Karolinum, s. 190.

ŠUBRT, J. 2000. Problém času v sociologické teorii. Praha: Karolinum.

ŠUBRT, J. „Čas a disciplína: Klášter jako model“. In: Sociologický časopis 1/1999.

ŠUBRT, J. 2000. „Sociologie jako věda, která zbavuje iluzí (Pierre Bourdieu)“. In.: Jedinec a společnost. Sborník k 65. narozeninám doc. PhDr. Jana Sedlácka, CSc. Praha: FF UK.

RƯŽIČKA, R.: ,,The Teacher's Role in Promoting Active Citizenship in a Transforming Society“. In: Saha, L. J. (ed.). Education and Active Citizenship. Educational Practice and Theory (Vol. 22, Melbourne 2000).

SUŠA, O.: „Globalizace, riziko a sociální souvislosti technologické změny“. In: Věda, technika, společnost, Teorie vědy IX, 1, 2000, s. 67-86.

BURIÁNEK, J. 2000. „Reflexe kriminality ve veřejném mínění“. In: AUC, Phil. et Hist. 4/1997, Studia sociologica XII, Praha: Karolinum, s. 135-156.

BURIÁNEK, J.: „Veřejnost a kriminalita v ČR: trendy vývoje“, Sociológia (vol. 32, No. 1) - Slovak Academic Press, Bratislava 2000, s. 80-97, ISSN 0049-1225.

BURIÁNEK, J.: „Crime Rates and Public Attitudes in the Czech Republic“. In: Sýkora J., (ed.). A New Dialogue between Central Europe and Japan: A Tension between Continuity and Change (Charles University, Praha 2000), ISBN 80-901206-5-2, s. 74-84.

BURIÁNEK, J.: „Bezpečnostní rizika a jejich percepce českou veřejností“, Sociologický časopis, r. 37 , 1/2001 (s. 43-64), ISSN 0038-0288.

RIEGEL, K. a kol. 2001. Vybrané psychologické problémy globalizace a transformace - úvodní studie. Praha: AGORA, (s. 9-31), ISBN 80-902945-2-9.

RIEGEL, K. 2001. „Globální ekonomika a psychologie práce“. In: Vybrané psychologické problémy globalizace a transformace. Praha: AGORA, s. 119-128.

RIEGEL K.: Referát na konferenci IAREP 2001, Bath, GB - Managers „Wellbeing and business ethics“. In: Proceedings: Environment and Wellbeing, s. 253-256.

JANOUŠEK, J. 2001. „Funkce vnitřní řeči při řešení problémủ u dítěte“. In: Hadjmoussová Z., Štech, S Ditě, škola - učitel - $k$ životnimu jubileu prof. Heluse. Praha: UK PedF, s. 67-72, ISBN 80-7290-057.

GILLERNOVÁ, I., MERTIN, V. (eds.). 2001. „Psychologické problémy člověka v měnícím se světě I“. In: AUC Phil. et Hist. 4/1998, Studia psychologica IX,. Praha: Karolinum 2001.

ŠÍPEK, J. 2001. Úvod do geopsychologie. Praha: ISV.

SLAMĚNÍK, I. 2001. „Emoce v sociální psychologii“. In: Výrost, Slaměník, I. (ed.). Aplikovaná sociální psychologie 2. Praha: Grada.

FRAŇKOVÅ, S. a kol. 2000. Výživa a vývoj osobnosti ditěte. Praha: HZ Editio.

HRACHOVINOVÁ, T. 2000. „Pracovní stres a syndrom vyhořeni“. In: Sestra v Evropské unii. Suppl. Sestra.

ŠTIKAR, J. 2000. „Požadavky na výcvik pracovníkủ v podmínkách organizace“. Seminář ČAPPO, Strážnice, sborník referátů.

ŠTURMA, J. a kol. Prvních 365 dní života dítěte. Česká verze Hellbruggeho skríningové metody. Praha: Testcentrum.

KASÍKOVÁ, H.: Kooperativní učení a vyučování. teoretické a praktické problémyy. Praha: Karolinum, 2001, S. 160.

KOŤA, J.: „Přirozený svět a domov - témata pro oblast výchovy“. In: Pedagogika 51, 1, 2001, s. 10-21. 
LORENZOVÁ, J.: „Komunita a její role v občanské společnosti“. In: Kraus, B., Poláčková, V. et al. 2001. Člověk - prostředi - výchova. K otázkám sociální pedagogiky. Brno: Paido, s. 119-125.

LORENZOVÁ, J. 2001. „Komunitní vzděláváni a komunitní škola“. In: Kraus, B., Poláčková, V. et al. Člověk - prostředí - výchova. K otázkám sociálni pedagogiky. Brno: Paido, s. 137-142.

LORENZOVÁ, J. 2001. „Pomáhání a pomáhající profese“. In: Kraus, B., Poláčková, V. et al. Clověk-prostředi - výchova. K otázkám sociální pedagogiky. Brno: Paido, s. 173-182.

VALENTA, J. 2000. Učit se být. Témata a metody pro osobnostní a sociálni výchovu. Praha-Kladno: STROM-AISIS, s. 95.

VALENTA, J. 2001. Výzkumný projekt ověrováni osobnostni a sociâlní výchovy ve školni praxi. Praha: FF UK, katedra pedagogiky, s. 12.

VALıŠOVÁ, A. 2001. „Problems of Authority in education“. In: Lust am Lehren. Klagenfurt: Leuchtturm-Verlag, s. 459-462.

VALIŠOVÁ, A. 1999. „Nezbytnost 'vůle k vůli' (vzájemné podněty praktické filozofie a pedagogiky)“. In: O filozofii výchovy a filozofii provádějicí (sborník praci věnovaný univ. prof. dr. Jaroslavě Peškové k jejim 70. narozeninám). Praha: FF UK, s. 83-89.

VALIŠOVÁ, A. 2000. Asertivita na prahu 21. století. Praha: RAABE, s. 1-16.

KRYKORKOVÁ, H., CHVÁL, M.: „Rozvoj metakognice - cesta k hodnotnějšímu poznání“. In: Pedagogika. č. 2, 2001, s. 185-196.

PELIKÁN, J. 2001. Pomáhat být. Otevřené otázky teorie provázející výchovy. AUC, Phil et Hist., Mono CLXI, Praha: Karolinum, s. 160.

MATĚJƯ, M. a kol. 1999. Kulturni a sociálni změny v lokálni společnosti - výzkum občanů 1992-98. Praha: FF UK.

MATËJŮ, M. a kol. 1999. Sociokulturni potenciál a vzdělanost v provesu revitalizace lokální společnosti. Praha: FF UK.

MATËJƯ, M. a kol. 2000. Transformace městských komunit v kontextu evropských integračnich procesủ (I. Český Krumlov, II. Blatná, III. Velké Meziříčí). Praha: FF UK.

MATĚJƯ, M. a kol. 2001. Transformace městských komunit. Kulturní a sociální změny v lokálni společnosti. Monografická studie. Výzkum obyvatel mĕsta Blatná. Informace z výzkumu prováděného v letech 1992 až 2000. Praha: katedra teorie kultury FF UK.

MATĚJÜ, M. a kol. 2001. Transformace městských komunit. Kulturni a sociální změny v lokálni společnosti. Monografická studie. Výzkum obyvatel města Český Krumlov. Informace z výzkumu prováděného $v$ letech 1992 až 2000. Praha: katedra teorie kultury FF UK.

MATĚJŮ, M. a kol. 2001. Transformace městských komunit. Kulturni a sociální změny v lokální společnosti. Monografická studie. Výzkum obyvatel města Velké Meziř̌čí. Informace z výzkumu provádĕného $v$ letech 1992 až 2000. Praha: katedra teorie kultury FF UK.

HAVRÁNEK, J., KOTRBÁČEK, J. 2000. „Konkurenční postavení zemědělských výrobců a jeho dủsledky“. In: Sborník: Transformation, Stabilization and Growth. Brno: MU, s. 131-144.

\section{Život dvou vynikajících polských sociologů se uzavřel}

Polská i světová sociologie utrpěla v létě roku 2001 citelnou ztrátu: 12. 7. zemřela Antonina Kłoskowská (nar. 7. 11. 1919) a 4. 8. skonal Edmund Mokrzycki (nar. 6. 1. 1937). Ačkoli byli přislušníky rủzných generací, získávajícími první poznatky o sociologii a zahajujícími svou vědeckou i pedagogickou dráhu v rozdílných dobách a za rủzných okolností, mnohé měli společné. Oba navazovali na nejlepši tradice polské sociologie, oba v řadě oborů sociologické práce tyto tradice tvořivým způsobem rozvíjeli, oba svými díly nepřehlédnutelným způso- bem obohatili sociologickou teorii, metodologii i některé odvětvové sociologické discipliny, oba mají výraznou zásluhu na tom, že polská sociologie se jako celek ani v období socialismu nezpronevěři la vědeckým standardům a oba získali i mezinárodní ohlas.

Antonina Kłoskowská ukončila studium sociologie na sklonku čtyřicátých let a hned poté začala vědecky a pedagogicky pracovat v Sociologickém 